\title{
MODELAGEM SÍSMICA TIME-LAPSE COM BASE EM DADOS DE SIMULAÇÃO DE FLUXO EM RESERVATÓRIOS
}

\author{
Carlos da Silva Claudino \\ Orientador: Dr. Wilson Mouzer Figueiró (UFBA) \\ 152 p. - Dissertação (Mestrado) - Defesa 17.05.2007
}

RESUMO. No presente trabalho, juntamos a simulação de reservatórios com a sísmica time-lapse, através da física de rochas e da modelagem. Nosso objetivo é investigar os principais efeitos das barreiras de permeabilidade na resposta sísmica, através da simulação de injeção de fluido. Para explorar este problema, criamos alguns experimentos de injeção de água e de gás em um modelo simples de reservatório com variações laterais e verticais de porosidade e com barreiras de permeabilidade. Em cada experimento, modificamos as propriedades das barreiras, a saber: porosidade e permeabilidade. Tanto para injeção de gás como para injeção de água, o tempo total de injeção foi 9 anos. Com a teoria da substituição de fluidos, através das equações de Gassmann e do modelo patchy, e as relações empíricas de Batzle e Wang, modelamos os principais atributos sísmicos, tais como: pressão, impedância acústica e velocidade compressional. Posteriormente, geramos inúmeros sismogramas sintéticos e algumas seções de contrastes para comparar as imagens das seções sísmicas obtidas no início da produção com as imagens em tempos subseqüentes e, assim, avaliar possíveis variações nos parâmetros sísmicos devido a mudanças nas propriedades das barreiras. A análise dos resultados revelou que a injeção de água não induz efeitos significativos na presença de barreiras. Por outro lado, a injeção de gás e o grau de impermeabilidade da barreira podem nos ajudar a compreender como a barreira atua na resposta sísmica e assim reduzir incertezas. Mostrou também que a presença de barreiras pode induzir um aumento de pressão no reservatório modificando o módulo de incompressão dos fluidos na região em que atua a barreira. Em síntese, esta dissertação apresenta uma metodologia para analisar efeitos de barreiras de fluxo na resposta sísmica.

ABSTRACT. In this project, we link the flow simulation with time-lapse seismic through rock physic and modeling. Our goal is to examine the main permeability barriers effects on seismic response using the flow simulations. To explore this problem, we have made some water and gas injection experiments in a simple reservoir model which has vertical and horizontal variations of porosity and permeability barriers. In each experiment, we change the barriers properties, especially: porosity and permeability. The total time of simulation is nine years in both cases. Across fluid substitution theory, Gassmann equations and patchy model, and Batzle and Wang's empirical relationship we model the main seismic parameters, such as: pressure, acoustic impedance and compressional velocity. After that, we generated many synthetic seismograms and some contrast sections to compare the seismic images between beginning production and subsequent times, and to analyze possible variations in the seismic parameters due to changes in barriers properties. The results show that barriers can increase fluid pore pressure, changing the bulk modulus in the barriers regions. They show also that water flow has not significant impact over seismic response when the barrier is present. On the other hand, the gas flow and the impermeability barrier degree can help us to understand how the barriers act on seismic response and thus to reduce uncertainty. Finally, this dissertation present a methodology to examine barriers effects on seismic response. 